\title{
PERBEDAAN SIKAP REMAJA TERHADAP SEKS BEBAS PADA SEKOLAH YANG MEMILIKI PUSAT INFORMASI DAN KONSELING REMAJA (PIK R) DAN YANG TIDAK MEMILIKI PIK R
}

\author{
Clarisa Noveria Erika Putri, Sumiyati, Aenun Nazikhatul Khusna, Risa Latunnisa, \\ Ika Khofifah, Tyas Oktavi Nastiti \\ Poltekkes Kemenkes Semarang \\ email: clarissaputri471@gmail.com
}

\begin{abstract}
Sexuality in adolescents can have detrimental consequences for adolescents themselves, their families and society. The consequences include infectious diseases such as venereal disease, HIV or AIDS and unwanted pregnancy. To avoid such frightening problems, one way to prevent it is the Youth Information and Counseling Center. However, not all secondary schools in Purwokerto have a Youth Information and Counseling Center. Research purposes is knowing the Differences in Attitudes of Adolescents to Free Sex in Schools That Have Adolescent Information and Counseling Centers and those that do not. Research methods is explanatory research using survey methods and the population of this study are all students who attend high school in Banyumas district that have an information and counseling center for adolescents and students who attend high school at schools that do not have an information center and youth counseling using cluster sampling technique. Results is there are differences in adolescent attitudes towards free sex in schools that have adolescent information and counseling centers and schools that do not have adolescent information and counseling centers. Conclusion is based on the average value, the attitude of respondents who have information and counseling centers for adolescents is more positive in responding to free sex.
\end{abstract}

Keywords: Adolescent Information and Counseling Centers; free sex; adolescents.

\begin{abstract}
ABSTRAK
Seksualitas pada remaja dapat membawa akibat yang merugikan bagi remaja itu sendiri, keluarga maupun masyarakat. Akibat yang ditimbulkan diantaranya penyakit menular seperti penyakit kelamin, HIV atau AIDS, kehamilan yang tidak diinginkan. Untuk menghindari masalah-masalah yang menakutkan seperti itu, salah satu pencegahannya dengan Pusat Informasi dan Konseling Remaja (PIK R). Namun tidak seluruh sekolah menengah di Purwokerto memiliki Pusat Informasi dan Konseling Remaja (PIK R). Tujuan penelitian yaitu untuk mengetahui Perbedaan Sikap Remaja Terhadap Seks Bebas Pada Sekolah Yang Memiliki Pusat Informasi Dan Konseling Remaja (PIK R) Dan Yang Tidak Memiliki PIK R. Metode penelitian yaitu penelitian penjelasan dengan metode survei dan populasi penelitian ini adalah seluruh siswa yang bersekolah menengah atas di Kabupaten Banyumas yang memiliki pusat informasi dan konseling remaja dan siswa-siswa yang bersekolah menengah atas pada sekolah yang tidak memiliki pusat informasi dan konseling remaja dengan teknik cluster sampling. Hasil penelitian yaitu ada perbedaan sikap remaja terhadap seks bebas pada sekolah yang memiliki pusat informasi dan konseling remaja (PIK R) dan sekolah yang tidak memiliki PIK R. Kesimpulan berdasarkan nilai rata-rata sikap responden yang memiliki pusat informasi dan konseling remaja (PIK R) lebih positif dalam menyikapi seks bebas.
\end{abstract}

Kata Kunci: PIK R; seks bebas; remaja. 


\section{Pendahuluan}

Hasil Sensus Penduduk tahun 2010 menunjukkan bahwa jumlah penduduk Indonesia sebesar 237,6 juta jiwa, 63,4 juta di antaranya adalah remaja yang terdiri dari laki-laki sebanyak 32.164.436 jiwa $(50,70$ persen) dan perempuan sebanyak 31.279.012 jiwa (49,30 persen). Besarnya jumlah penduduk kelompok remaja ini akan sangat mempengaruhi pertumbuhan penduduk di masa yang akan datang. Penduduk kelompok umur 10-19 tahun perlu mendapat perhatian serius mengingat mereka masih termasuk dalam usia sekolah dan mereka akan memasuki umur reproduksi. Apabila tidak dipersiapkan dengan baik remaja sangat berisiko terhadap perilaku seksual pranikah, sehingga akan mengakibatkan ledakan penduduk yang sangat tinggi untuk beberapa tahun ke depan.

Dalam komponen Kesehatan Reproduksi Remaja SDKI 2012, responden ditanyakan bagaimana pendapat dan praktik dalam perilaku seksual. Penerimaan terhadap perilaku hubungan seksual pranikah sangat rendah. Secara umum, persentase wanita yang menyetujui hubungan seksual pranikah lebih sedikit daripada pria. Hanya satu persen dari responden wanita dan empat persen dari responden pria yang menyatakan wanita boleh melakukan hubungan seksual sebelum menikah. Stigmanya, kecenderungan pria untuk melakukan hubungan seksual pranikah lebih sedikit daripada wanita; sebanyak dua persen dari wanita dan tujuh persen dari pria, menyatakan bahwa mereka menyetujui pria yang melakukan hubungan seksual sebelum menikah.

Masalah seksualitas pada masa remaja menjadi pembicaraan yang selalu menarik bagi siapa saja. Namun seksualitas pada remaja tersebut dapat membawa akibat yang merugikan bagi remaja itu sendiri, keluarga maupun masyarakat. Akibat yang ditimbulkan karena seksualitas pada remaja itu di antaranya penyakit menular seperti penyakit kelamin, HIV atau AIDS, kehamilan yang tidak diinginkan. Tanggung jawab moral yang terjadi akibat seksualitas pada remaja tidak hanya ditanggung oleh remaja itu sendiri tapi juga keluarga, pendidik dan masyarakat. Menurut Dr Boyke Dian Nugraha, jika hubungan seks tersebut dilakukan sebelum usia 17 tahun, risiko terkena penyakit menular seksual bisa mencapai empat hingga lima kali lipat. Selain itu, seks pranikah akan meningkatkan kasus penyakit menular seksual, seperti sipilis, GO (gonorhoe), hingga HIVIAIDS.

Banyak hal yang bisa melatar belakangi perilaku tersebut antara lain pengetahuan remaja yang kurang, kasih sayang dari keluarga yang hampir tidak dirasakan, terlalu terkekang dengan aturan orang tua, serta kebutuhan akan pengakuan yang tidak terpenuhi membuat remaja kadang memilih jalan yang salah. Motivasi untuk melakukan hubungan seksual itu sendiri dapat muncul akibat bujukan atau permintaan pacar, rasa ingin tahu, agama atau keimanan yang kurang kuat serta terinspirasi dari film dan media massa (Bobak, 2004; Soetjiningsih, 2004; AlMighwar, Muhammad, 2006)..

Untuk menghindari masalah-masalah yang menakutkan seperti yang disebutkan tadi, salah satunya pencegahnya yaitu dengan Pusat Informasi dan Konseling Remaja (PIK R). Melalui PIK R diadakan sosialisasi kepada antar sesama remaja. Dari remaja, kepada remaja, dan untuk remaja. Karena biasanya remaja lebih cenderung terbuka dengan teman-temannya, dari pada guru, jadi setidaknya permasalahan yang ada dapat diselesaikan melalui proses konseling bersama teman. Dengan adanya PIK $R$ mungkin bisa menjadi alternatif yang efektif dalam memecahkan masalah yang dihadapi remaja. Namun tidak seluruh sekolah menengah di Purwokerto memiliki Pusat Informasi dan Konseling Remaja (PIK R).

Persoalan persetubuhan anak di bawah umur di Kabupaten Banyumas cukup meningkat, menurut Kapolres Banyumas AKBP Bambang Yudhantara Salamun Sik dalam kurun waktu Januari 2018, tercatat ada sembilan kasus yang sudah di laporkan ke Polres Banyumas. Kasus yang paling baru yakni hubungan kedua remaja. Di sisi lain ada sekolah yang mampu memiliki 
prestasi juara tingkat Provinsi dan maju ke tingkat nasional dalam pengelolaan PIK R.

\section{Metode Penelitian}

Jenis penelitian yang digunakan adalah penelitian penjelasan dengan metode survey berlokasi di sekolah menengah atas yang memiliki pusat informasi dan konseling remaja serta sekolah menengah atas yang tidak memiliki pusat informasi dan konseling remaja.

Subyek dalam penelitian ini adalah remaja yang bersekolah di SMA yang memiliki PIK-R dan yang tidak memiliki PIK$\mathrm{R}$ di wilayah Kabupaten Banyumas. Teknik pengambilan sampel dengan non-probability sampling menggunakan pendekatan purposive sampling. Berdasarkan kriteria yang sudah ditetapkan sebelumnya.

Penelitian dimulai dengan mengurus perizinan, melakukan validasi sampel di sekolah yang memiliki PIK-R dan yang tidak memiliki PIK-R, dilanjutkan dengan membagikan kuesioner kepada siswa, dan setelah itu mengolah data penelitian berdasarkan hasil kuesioner tersebut.

\section{Hasil dan Pembahasan}

Responden yang berpartisipasi dalam penelitian ini sebanyak 179 orang yang terbagi dalam dua kelompok, yaitu kelompok remaja yang di sekolahnya memiliki PIK-R yaitu pada SMA Ada PIK-R dan kelompok remaja yang di sekolahnya tidak memiliki PIK-R . Hasil observasi sebagai berikut :

Tabel 1 Jenis Kelamin Responden pada SMA Ada PIK-R dan SMA N 1 Baturraden

\begin{tabular}{ccccc}
\hline $\begin{array}{c}\text { Jenis } \\
\text { Kelamin }\end{array}$ & $\begin{array}{c}\text { SMAAda } \\
\text { PIK-R }\end{array}$ & $\begin{array}{c}\text { SMA Tidak Ada } \\
\text { PIK-R }\end{array}$ \\
\cline { 2 - 5 } & $\mathrm{N}$ & $\%$ & $\mathrm{~N}$ & $\%$ \\
\hline Laki-laki & 43 & $44 \%$ & 29 & $35 \%$ \\
\hline Perempuan & 55 & $56 \%$ & 53 & $65 \%$ \\
\hline
\end{tabular}

Tabel 1 memberikan gambaran ratarata jenis kelamin dari responden yang diobservasi selama penelitian pada SMA Tidak Ada PIK-R adalah berjenis kelamin perempuan sebanyak 53 responden dengan prosentase $65 \%$. Sedangkan yang berjenis kelamin laki-laki sebanyak 29 responden dengan prosentase $65 \%$. Sedangkan ratarata jenis kelamin dari responden yang diobservasi selama penelitian pada SMA Ada PIK-R adalah berjenis kelamin perempuan sebanyak 54 responden dengan prosentase $56 \%$. Sedangkan yang berjenis kelamin laki-laki sebanyak 43 responden dengan prosentase $44 \%$.

Tabel 2 Usia Responden pada SMA Ada PIK-R dan SMA Tidak ada PIK-R

\begin{tabular}{ccccc}
\hline Usia & \multicolumn{2}{c}{$\begin{array}{c}\text { SMA Tidak } \\
\text { Ada PIK-R }\end{array}$} & \multicolumn{2}{c}{$\begin{array}{c}\text { SMAAda } \\
\text { PIK-R }\end{array}$} \\
\cline { 2 - 5 } & $\mathrm{N}$ & $\%$ & $\mathrm{~N}$ & $\%$ \\
\hline 14 tahun & 1 & $1,2 \%$ & 0 & $0 \%$ \\
\hline 15 tahun & 25 & $30,5 \%$ & 5 & $5,1 \%$ \\
\hline 16 tahun & 32 & $39 \%$ & 57 & $58,8 \%$ \\
\hline 17 tahun & 20 & $24,4 \%$ & 29 & $29,9 \%$ \\
\hline 18 tahun & 3 & $3,7 \%$ & 6 & $6,2 \%$ \\
\hline 19 tahun & 1 & $1,2 \%$ & 0 & $0 \%$ \\
\hline
\end{tabular}

Tabel 2 memberikan gambaran ratarata usia dari responden yang diobservasi selama penelitian pada SMA Tidak Ada PIK$\mathrm{R}$ adalah berusia 16 tahun sebanyak 32 responden dengan prosentase $39 \%$. Sedangkan rata-rata usia dari responden yang diobservasi selama penelitian pada SMA Ada PIK-R adalah berusia 16 tahun sebanyak 57 responden dengan prosentase $58,8 \%$.

Responden dalam penelitian berjumlah 179 orang sehingga yang digunakan adalah uji Kolmogorov Smirnov. Hasil uji tersaji pada tabel 3.

Tabel 3 Uji Kolmogorov Smirnov pada Data SMA Ada PIK-R dan SMA Tidak Ada PIK-R

\begin{tabular}{cccc}
\hline Variabel & Statistic & $d f$ & Sig. \\
\hline $\begin{array}{c}\text { SMAAda } \\
\text { PIK-R }\end{array}$ & 0.092 & 82 & 0.085 \\
\hline $\begin{array}{c}\text { SMA N 1 } \\
\text { Baturraden }\end{array}$ & 0.083 & 82 & 0.200 \\
\hline
\end{tabular}


Tabel 3 menggambarkan uji menggunakan kolmogorov smirnov karena jumlah sampel yang diteliti lebih dari 50 responden yaitu sebanyak 179 responden. Hasil data berdistribusi normal, dilihat dari $p>0,05$.

Tabel 4 Uji Nilai Sikap pada SMA Ada PIK R dan SMA Belum Ada PIK R

\begin{tabular}{lclllc}
\hline $\begin{array}{l}\text { Sikap } \\
\text { PIK R }\end{array}$ & $N$ & Min & Max & Mean & SD \\
\hline Ada & 97 & 1,37 & 4 & 98.23 & 6.95487 \\
\hline $\begin{array}{l}\text { Belum } \\
\text { ada }\end{array}$ & 82 & 1,47 & 3,97 & 86.29 & 5.40116 \\
\hline
\end{tabular}

Berdasarkan hasil analisis uji nilai sikap diketahui perbandingan mean rangking sikap remaja pada sekolah yang ada pusat informasi dan konseling remaja (PIK R) dan sekolah yang belum PIK R yaitu 11.9444.

Tabel 5 Uji Beda SMA dengan PIK R dan SMA tanpa PIK R Terhadap Sikap Remaja Terhadap Seks Bebas

\begin{tabular}{llllll}
\hline & Mean & $\begin{array}{c}\text { Standar } \\
\text { deviasi }\end{array}$ & $\mathrm{t}$ & $\mathrm{p}$ \\
\cline { 1 - 2 } $\begin{array}{l}\text { SMA } \\
\text { dengan }\end{array}$ & 98.2371 & 6.95487 & & \\
$\begin{array}{l}\text { PIK R } \\
\text { SMA }\end{array}$ & 86.2927 & 5.40116 & & \\
$\begin{array}{l}\text { tanpa } \\
\text { PIK R }\end{array}$ & & & & \\
\hline
\end{tabular}

Data diperoleh t 12,655 dan p 0,0001, dapat disimpulkan $\mathrm{Ho}$ ditolak dan $\mathrm{Ha}$ diterima, sehingga secara statistik pada penelitian ini ada perbedaan sikap remaja pada sekolah yang memiliki pusat informasi dan konseling remaja (PIK R) dan yang tidak memiliki PIK R. Bedasarkan nilai rata-rata sikap responden yang ada pusat informasi dan konseling remaja (PIK R) lebih positif dalam menyikapi seks bebas.

Hasil penelitian mengenai perbedaan sikap remaja terhadap seks bebas pada sekolah yang memiliki pusat informasi dan konseling remaja (PIK R) menunjukan dari 97 responden hasil tertinggi yang memiliki sikap positif terhadap seks bebas rata-rata berusia 16 tahun sebanyak 57 responden dengan presentasi $58,7 \%$. Pada penelitian ini respondennya adalah remaja yang bersekolah di SMA Ada PIK-R sebagian besar memiliki sikap positif terhadap seks bebas. Remaja yang bersekolah di SMAAda PIK-R termasuk dalam kategori positif artinya tidak mendukung terhadap seks bebas dan memiliki sikap baik artinya tidak mendukung seks bebas. Dengan ini remaja yang menolak perilaku seks bebas maka remaja akan memiliki masa depan yang baik. Hal ini ada perbedaan sikap remaja terhadap seks bebas pada sekolah yang memiliki PIK R dan tidak memiliki PIK R dan perbedaan tersebut signifikan.

Berdasarkan hasil penelitian menunjukkan bahwa responden yang sudah pernah mendapatkan informasi tentang seks bebas dan hasilnya menunjukkan sebagian besar memiliki sikap positif. Terbukti inforrmasi yang didapatkan diaplikasikan dengan baik, karena sangat memahami bahwa dampak dari seks bebas itu sangat merusak masa depan mereka dan juga menimbulkan hal yang buruk terhadap orang tua mereka. Terbukti dengan hasil penelitian Rahmawati dan Cantika (2018) bahwa remaja dapat mengaplikasikan informasi dengan baik remaja sebagian bersikap positif. Kurangnya seks bebas, berdampak pada kurangnya pengetahuan remaja mengenai pendidikan seksual, terutama yang berhubungan dengan seks bebas. Informasi yang kurang tentang seks bebas dapat menyebabkan remaja berperilaku kearah seks bebas. Banyak remaja melakukan seks bebas karena rasa penasaran mereka.

Penelitian Wulandari (2015) menunjukan bahwa responden yang memiliki pegetahuan tinggi dan sikap positif akan lebih cenderung untuk memanfaatkan PIK R. Selain itu, penelitian Widyawati, dkk (2017) menunjukan bahwa terdapat perbedaan tingkat pengetahuan dan sikap tentang kesehatan reproduksi antara sekolah yang menerapkan program PIK-R dan sekolah yang tidak menerapkan program PIK $R$, dimana responden yang berpengetahuan tinggi dan bersikap lebih positifa lebih banyak pada sekolah yang menerapkan PIKR. 
Hasil penelitian Azinar (2013) menyatakan perilaku seksual teman dekat, sikap responden terhadap seksualitas, dan religiusitas dominan mempengaruhi perilaku seksual pranikah berisiko kehamilan Tidak diinginkan (KTD). Penelitian Liana (2018) menunjukan bahwa sikap siswa yang mengikuti PIK $R$ dengan yang tidak mengikuti PIK $R$ ada perbedaan, karena siswa yang mengikuti PIK $R$ pengetahuannya lebih baik dibandingkan dengan yang tidak ikut ikut PIK R, sehingga sikap siswa berbada. Semakin positif sikap remaja terhadap perilaku seksual maka semakin besar intensinya untuk tidak melakukan perilaku seksual secara bebas dan menjaga kesehatan reproduksinya, sedangkan remaja yang memiliki sikap yang negatif terhadap perilaku seksual akan semakin besar intensinya untuk melakukan perilaku seksual.

Berbeda dengan penelitian Juliana dkk. (2018) bahwa tidak terdapat perbedaan tingkat pengetahuan dan sikap siswa SMP tentang kesehatan reproduksi remaja berdasarkan keikutsertaan pada program PIK-R dengan $p$-value pengetahuan 0,372 dan $p$-value sikap 0,104.

Penelitian yang dilakukan oleh Wijaya (2017) menunjukkan terdapat perbedaan skor rata-rata pengetahuan dan sikap siswa di sekolah yang menerapkan PIK-R dan di sekolah yang tidak menerapkan PIK-R. Siswa yang berada di sekolah yang menerapkan PIK-R memiliki pengetahuan dan sikap yang lebih baik dibandingkan dengan siswa yang berada disekolah yang tidak menerapkan PIK-R

Hasil penelitian lain Khairani dan Putri (2008) membuktikan terdapat perbedaan yang signifikan antara kematangan emosi pada pria dan wanita yang menikah muda, di mana ditemukan bahwa pria memiliki kematangan emosi lebih tinggi dibandingkan wanita. Penelitian Mertia dkk. (2010) menyatakan ada hubungan yang signifikan secara statistik antara pengetahuan seksualitas dan kualitas komunikasi orangtua dan anak dengan perilaku seks bebas pada remaja

\section{Kesimpulan}

Rata-rata usia dari responden yang diobservasi selama penelitian pada SMA Ada PIK-R dan SMA Tidak Ada PIK-Radalah berusia 16 tahun. Sedangkan rata-rata jenis kelamin responden pada kedua sekolah tersebut adalah berjenis kelamin perempuan.

Hasil analisis uji nilai sikap diketahui sikap remaja pada sekolah yang ada pusat informasi dan konseling remaja (PIK R) memiliki mean rangking 98,2371 sedangkan sikap remaja pada sekolah yang belum ada pusat informasi dan konseling remaja (PIK R) memiliki mean rangking 86,2927. Dengan demikian mean sikap remaja yang pada sekolah ada PIK R lebih tinggi dibandingkan dengan sikap remaja pada sekolah yang belum ada PIK $R$ dan perbandingan mean rangking sikap remaja pada sekolah yang ada pusat informasi dan konseling remaja (PIK R) dan sekolah yang belum PIK R yaitu 11.9444

Dari data diperoleh t 12,655 p 0,0001. Dengan demikian secara statistic pada penelitian ini ada perbedaan sikap remaja pada sekolah yang memiliki pusat informasi dan konseling remaja (PIK R) dan yang tidak memiliki PIK R. Bedasarkan nilai rata-rata sikap responden yang ada pusat informasi dan konseling remaja (PIK R) lebih positif dalam menyikapi seks bebas.

\section{Ucapan Terima Kasih}

Terimakasih banyak kami ucapkan untuk kesempatannya bisa mendapatkan dana Risbinakes DIPA Poltekkes Kemenkes Semarang, sehingga penelitian ini dapat terselesaikan. Ucapan terimakasih disampaikan kepada semua pihak yang ikut berpartisipasi dalam penelitian ini.

\section{Daftar Pustaka}

Al-Mighwar, Muhammad. (2006). Psikologi Remaja. Bandung: Pustaka Setia Bandung.

Bobak, Lowdermilk, \& Jensen. (2004). Buku Ajar Keperawatan Maternitas. Edisi keempat. Jakarta: EGC. 
Liana, Intan. (2018). Efektivitas Program Generasi Berencana Pusat Informasi Konseling (PIK) Remaja Bagi Siswa SMA Negeri Di Kota Banda Aceh. Jurnal Avverous, Volume 4, No. 2, hal: 187-189.

Mertia, E. N, Hidayat, T., Yuliadi, I. (2011). Hubungan Antara Pengetahuan Seksualitas Dan Kualitas Komunikasi Orang Tua Dan Anak Dengan Perilaku Seks Bebas Pada Remaja Siswa Siswi MAN Gondangrejo Karanganyar, Jurnal Wacana Psikologi, Volume 3 No 2.

Azinar, Muhammad (2013). Perilaku Seksual Pranikah Berisiko Terhadap Kehamilan Tidak Diinginkan. Jurnal Kesehatan Masyarakat, Volume 5, No. 3 , hal: 153-160.

Khairani, R. \& Putri, D. E. (2008). Kematangan Emosi Pada Pria Dan Wanita Yang Menikah Muda. Fakultasi Psikologi Universitas Gunadarma. Jurnal Psikologi, Volume 1 No. 2, hal: 120-123.

Rahmawati, D. \& Cantika H. P. (2018). Hubungan Pengetahuan dengan Sikap Remaja Tentang Seks Bebas. Jurnal Kebidanan Dharma Husada, Volume 7 No. 1, hal: 171-176.

Soetjiningsih. (2004). Tumbuh Kembang Remaja Dan Permasalahannya. Jakarta: Sagung Seto.

Survei Demografi Dan Kesehatan Indonesia. (2012). Kesehatan Reproduksi Remaja Badan Pusat Statistik, Badan Kependudukan Dan Keluarga Berencana Nasional, Kementerian Kesehatan, Measure Dhs, ICF International.

Juliana, I., Rahmayanti, D., Damayanti, E. A.,F., (2018) Tingkat Pengetahuan Dan Sikap Siswa Smp Tentang Kesehatan Reproduksi Remaja Berdasarkan Keikutsertaan Pada Program Pusat Informasi Dan Konseling-Remaja (PIK-R), Dunia Keperawatan, Volume 6, Nomor 2.

Widyawati, S.A., Lestari I.P., \& Najib. (2017). Perbedaan Tingkat pengetahuan kesehatan reproduksi dan premarital seks berdasarkan layanan PIK-KRR pada Siswa SMK Swasta, Universitas Ngudi Waluyo

Wulandari S. (2015). Hubungan Pengetahuan, Sikap, dan Perilaku Pencegahan Penyakit Menular Seksual (PMS) dan HIVIAIDS dengan Pemanfaatan Pusat Informasi dan Konseling Remaja (PIK R) pada Remaja SMKN Tandun Kabupaten Rokan Hulu. Jurnal Maternity and Neonatal, Volume 2 No. 1, hal: 134136.

Wijaya, C.S. (2017) Perbedaan Tingkat Pengetahuan Dan Sikap Siswa SMP Tentang Kesehatan Reproduksi di SMP yang menerapkan PIK-R dan tidak menerapkan PIK-R. Universitas Muhammadiyah Surakarta. pp.1-1 